\title{
CANADINE SYNTHASE FROM THALICTRUM TUBEROSUM CELL CULTURES CATALYSES THE FORMATION OF THE METHYLENEDIOXY BRIDGE IN BERBERINE SYNTHESIS
}

\author{
Martina Rueffer* and Meinhart H. Zenk \\ Lehrstuhl für Pharmazeutische Biologıe, Universität München, Karlstr. 29, 80333 München, Germany
}

(Received 8 February 1994)

\begin{abstract}
Key Word Index-Thalictrum tuberosum; Ranunculaceae; protoberberine alkaloids; canadine syn-
\end{abstract} thase; cytochrome P-450; biosynthesis.

\begin{abstract}
An enzyme system catalysing the formation of the methylenedioxy bridge at ring $A$ of $(S)$-canadine $[=(S)$ tetrahydroberberine] from $(S)$-tetrahydrocolumbamine has been detected in microsomal preparations from different Ranunculaceae and Berberidaceae cell cultures. The cytochrome P-450 enzyme complex has been partly characterized from a protoberberine alkaloid producing Thalictrum tuberosum L. cell line. The enzyme complex consisting of a microsomal associated oxidase with a cytochrome $\mathrm{P}-450$ reductase has a $\mathrm{pH}$ optimum at $\mathrm{pH} 8.5$ and a temperature optimum of $40^{\circ}$. The apparent $K_{m}$ values are $33 \mu \mathrm{M}$ for NADPH and $11.5 \mu \mathrm{M}$ for tetrahydrocolumbamine.
\end{abstract}

\section{INTRODUCTION}

A considerable number of natural products contain methylenedioxy groups in their structure. In vivo experiments employing $\left[{ }^{14} \mathrm{C}\right]$-labelled precursors demonstrated that the methylenedioxy groups, found especially in benzylisoquinoline alkaloids, are derived by cyclization of an ortho-methoxyphenol to furnish the methylenedioxy ring [1-3]. The first report of an enzyme reaction catalysing the methylenedioxy formation appeared [4] when two highly stereo- and regiospecific microsomal cytochrome P.450-, NADPH-, and $\mathrm{O}_{2}$ dependent enzymes were discovered and partly characterized. These enzymes were responsible for the sequential introduction of two methylenedioxy groups from the substrate, (S)-scoulerine, via (S)-cheilanthifoline to $(S)$ stylopine. This system was further characterized [5] and more recently shown to consist of two separable cytochrome P-450 enzymes catalysing each of the methylenedioxy group formations first in the D-ring, leading from $(S)$-scoulerine to $(S)$-cheilanthifoline and subsequently in the A-ring of this molecule, leading from $(S)$ cheilanthifoline to (S)-stylopine [L. Kammerer and M. H. Zenk, unpublished results]. Due to the fact that cytochrome P-450-dependent monooxygenases are involved in the methylenedioxy bridge formation, we assume that this group is initiated via hydroxylation of the attached methoxy group. This step would generate a hemiformal, possibly representing the crucial intermediate in the reaction mechanism [3].

In a previous attempt to develop an assay system for the analysis of the methylenedioxy bridge formation in

*Author to whom correspondence should be addressed. the conversion of columbamine to berberine in Berberis cell cultures, the expected release of one third of the tritium atoms residing in the $\left[3-\mathrm{O}-\mathrm{C}^{3} \mathrm{H}_{3}\right]$-group of columbamine was used by Rueffer and Zenk [6] as a criterion to measure the activity of the suspected berberine synthase'. Activity of an $\mathrm{Fe}^{2+}$-containing cytosolic enzyme was detected, showing at $\mathrm{pH} 8.9$ the typical protoporphyrine absorption at $408 \mathrm{~nm}$ and an unusual high temperature optimum at $70^{\circ}$. The enzyme was isolated and purified to homogeneity but the suspected 'berberine synthase' turned out, however, to be a peroxidase. This enzyme was studied using [3-O${ }^{14} \mathrm{CH}_{3}$ ] columbamine as substrate [7]. The peroxidase did not form a methylenedioxy bridge, thus not yielding berberine, but rather catalysed the demethylation of the [3-O- $\mathrm{CH}_{3}$ ]-group of columbamine [7]. The yield of radioactivity released into the medium was exactly $30 \%$, which was previously interpreted [6] as the loss of one third of the $\left[{ }^{3} \mathrm{H}\right]$-atoms in the methyl group of columbamine during the transition to the methylenedioxy group. The claimed [6] 'berberine synthase' is, therefore, incorrect as shown by Bauer et al. [7]; the originally observed enzyme activity was an artifact.

Both Berberis and Coptis cell cultures [8,9] have been used in the past to clarify the biosynthesis of berberine at the enzymic level $[10,11]$. The last step in berberine biosynthesis, which still remains to be clarified, is the formation of the methylenedioxy group in the transition of $(S)$-tetrahydrocolumbamine to $(S)$-canadine.

Since both cell cultures from the families Berberidaceae and Ranunculaceae produce profuse amounts of berberine, cell cultures of both families were used for the detection of an enzyme or enzyme system possibly catalysing this remaining biosynthetic step. The metabolic 
route leading from $(S)$-tetrahydrocolumbamine to berberine has not yet been investigated at the enzymic level and is the subject of this study. It is shown that, similarly to the stylopine forming system of Eschscholtzia [5], the methylenedioxy bridge formation of berberine is catalysed by a specific cytochrome P-450-dependent enzyme.

\section{RESULTS AND DISCUSSION}

The substrate used for the detection of the enzyme catalysing the formation of the methylenedioxy group of canadine from tetrahydrocolumbamine was synthesized enzymically by incubating 2,3-dihydroxy-9,10-dimethoxyprotoberberine with $\left[{ }^{14} \mathrm{CH}_{3}\right] S$-adenosyl-L-methionine and commercially available catechol- $O$-methyltransferase. In the presence of $\mathrm{O}_{2},\left[3-\mathrm{O}^{14} \mathrm{CH}_{3}\right]$ columbamine was formed ( $80 \%$ yield) and subsequently reduced with $\mathrm{NaBH}_{4}$. A new assay system was developed in which the $\left[{ }^{14} \mathrm{C}\right]$-labelled, TLC-purified substrate was incubated together with various protein fractions isolated from a range of cell cultures. The expected labelled products (canadine or berberine) were separated from the substrate by TLC and were subsequently quantitated by TLCradioscanning.

Incubation of $(\mathrm{R}, \mathrm{S})-\left[3-\mathrm{O}_{-}^{14} \mathrm{CH}_{3}\right]$ tetrahydrocolumbamine with crude protein extracts from different Ranunculaceae and Berberis cell cultures did not lead to the formation of compounds with methylenedioxy bridges. However, when microsomal preparations were isolated from different species of Berberidaceae and Ranunculaceae and incubated with either $\left[3-\mathrm{O}^{14} \mathrm{CH}_{3}\right]$ tetrahydrocolumbamine or $\left[3-\mathrm{O}^{14} \mathrm{CH}_{3}\right]$ columbamine, a clear but differential formation of berberine could be detected (Table 1) from tetrahydrocolumbamine. Columbamine did not serve as substrate for this reaction. The question remained why berberine was formed instead of the expected canadine. This was due to the activity of $(S)$ tetrahydroprotoberberine oxidase (STOX) which cata-

Table 1. Occurrence of canadine synthase in plant cell cultures

\begin{tabular}{lc}
\hline Tissue culture & $\begin{array}{c}\text { Enzyme activity6 } \\
\text { (pkat }]^{-1} \text { medium) }\end{array}$ \\
\hline Berberis aristata DC. & 2.6 \\
B. crataegina DC. & 5.5 \\
B. taliensis Schneid. & 0.9 \\
B. stolonifera Koehne \& E. Wolf & 2.6 \\
B. henryana Schneid. & 0.7 \\
B. notabilis Schneid. & 0 \\
Coptis japonica Mak. & 1.6 \\
Thalictrum glaucum Desf. & 2.1 \\
T. glabrum K. Koch & 4.4 \\
T. macrocarpum Gren. & 0.7 \\
T. tuherosum L. & 10.4 \\
Ycllow cell line & 5.5 \\
\hline
\end{tabular}

The values were determined with tetrahydrocolumbamine as substrate measured under standard assay conditions. Activity was not detected when columbamine was used as substrate. lyses the oxidation of $(S)$-tetrahydroprotoberberines to the corresponding protoberberines [12]. This contaminating enzyme (STOX) was present in considerable quantities in the microsomal fraction oxidizing both the substrate tetrahydrocolumbamine and the product canadine to their corresponding protoberberines, i.e. columbamine and berberine. This enzyme could not be selectively inhibited nor could the vesicles in which the STOX enzyme is contained [13] be separated from the microsomal preparations by differential centrifugation. Comparison of the enzyme activities showed that the highest transformation of $\left[{ }^{1+} \mathrm{CH}_{3}\right]$ tetrahydrocolumbamine to berberine was found in a protoberberine-containing, yellow-coloured cell line of Thalictrum tuberosum (Table 1), which was used for further experiments. The reaction product of the transformation had been identified only by TLC-radioscanning and, therefore, the identity of the product had to be rigorously established. For the identification of the reaction product, twenty standard incubation assays were combined, the radioactively labelled product $\left(13.3 \times 10^{6} \mathrm{dpm} \mu \mathrm{mol}^{1}\right)$ was reduced with $\mathrm{NaBH}_{4}$ to $(R, S)$-canadine $\left(11.7 \times 10^{6} \mathrm{dpm} \mu \mathrm{mol}^{-1}\right)$, and diluted with unlabelled $(R, S)$-canadine resulting in a specific activity of $2.2 \times 10^{4} \mathrm{dpm} \mu \mathrm{mol}{ }^{-1}$. This compound was recrystallized three times from $\mathrm{MeOH}$. The specific activity remained constant at $2.0 \times 10^{4} \mathrm{dpm} \mu \mathrm{mol}^{-1}$. This experiment clearly identified the reaction product of the $\left[{ }^{14} \mathrm{C}\right]$ tetrahydrocolumbamine incubation as berberine which had been formed via canadine by oxidation with STOX that contaminated the microsomal fraction.

The reaction was dependent on NADPH. Replacement of NADPH with NADH showed a reaction rate of only ca $21 \%$. A synergistic effect achieved by adding both NADPH and NADH, which had been observed previously in cytochrome $P-450$-catalysed reactions [14], was not observed here. Replacement of NADPH with NAD, NADP, FAD or FMN showed no reaction. The enzyme was inactive in the absence of $\mathrm{O}_{2}$, as shown by the removal of $\mathrm{O}_{2}$ by a glucose oxidase/catalase system [15]. The formation of the methylenedioxy bridge in the presence of $\mathrm{O}_{2}$ and NADPH could be strongly inhibited by carbon monoxide. The inhibition could be partially reversed by illumination with white light (Table 2). Further analysis showed that predominantly blue light (wavelength $438 \mathrm{~nm}$ ) was responsible for this reversal (data not

Table 2. Effect of carbon monoxide and light on microsomal bound canadine synthase activity from $T$. tuberosum cell cultures under standard incubation conditions

\begin{tabular}{lcc}
\hline Assay condition & $\begin{array}{l}\text { Relative } \\
\text { enzyme } \\
\text { actuvity }(\%)\end{array}$ & $\begin{array}{l}\text { Product } \\
\text { formed } \\
\text { (nmol) }\end{array}$ \\
\hline Air & 100 & 73 \\
$\mathrm{~N}_{2} / \mathrm{O}_{2}(9: 1)$ (light) & 100 & 73 \\
$\mathrm{~N}_{2}: \mathrm{O}_{2}(9: 1)$ (dark) & 98 & 53 \\
$\mathrm{CO} / \mathrm{O}_{2}(9: 1)$ (dark) & 8.5 & 6 \\
$\mathrm{CO}: \mathrm{O}_{2}(9: 1)$ (white light) & 55.5 & 39 \\
\hline
\end{tabular}


Table 3. Effect of inhibitors of cytochrome P-450 enzymes on microsomal bound canadine synthase from $T$. tuberosum cell cultures

\begin{tabular}{lccc}
\hline & $\begin{array}{c}\text { Product } \\
\text { Concentration } \\
\text { formed } \\
(\mathrm{pmol})\end{array}$ & $\begin{array}{l}\text { Inhibition } \\
(\%)\end{array}$ \\
\hline None & 0 & 99 & 0 \\
Ketoconazole & 300 & 0 & 100 \\
Prochloraz & 35 & 50 & 50 \\
& 300 & 0 & 100 \\
Tetcyclacis & 35 & 50 & 50 \\
Metyrapone & 35 & 0 & 100 \\
Propiconazole & 300 & 58 & 41 \\
Tropolone & 300 & 72 & 27 \\
Triadimefone & 300 & 58 & 41 \\
Plumbagin & 35 & 62 & 37 \\
Juglone & 0.35 & 50 & 100 \\
& 3.5 & 15 & 50 \\
Menadione & 0.35 & 48 & 85 \\
& 3.5 & 0 & 52 \\
Cytochrome $c$ & 17 & 50 & 100 \\
& 170 & 0 & 50 \\
& & 0 & 100 \\
\hline
\end{tabular}

The standard incubation assays containing 0.5 pkat of the enzyme were incubated with the inhibitor concentrations shown in the table.

shown). A second indication for the involvement of a cytochrome P-450 enzyme in the formation of the methylenedioxy bridges of canadine and berberine was the inhibition of the reaction by typical cytochrome P-450 inhibitors (Table 3). Inhibitors such as ketoconazole, tetcyclacis and the naphthoquinones, plumbagin, menadione and juglone, which interact with heme group [16], strongly inhibited the formation of the methylenedioxy bridge under the conditions given in Table 3. Strong inhibition was also observed by addition of cytochrome $c$ which extracts electrons formed by the NADPH-cytochrome $c$-reductase from the enzyme complex (Table 3 ). The content of cytochrome P-450 in the microsomal preparations was determined by the method of Omura and Sato [17] to be $163 \mathrm{pmol} \mathrm{mg}^{-1}$, which falls within the normal range determined for higher plants [18]. The enzyme system transforming tetrahydrocolumbamine to canadine has been named canadine synthase. Canadine is the preferred name over tetrahydroprotoberberine (which includes canadine) because tetrahydroberberine tends to be confused with the tetrahydroprotoberberines and a specific oxidase like STOX (tetrahydroprotoberberine oxidase [12]) is readily confused with tetrahydroberberine oxidase [19].

The physical characteristics of canadine synthase were as follows. The optimal reaction rate was observed at $\mathrm{pH}$ 8.5 in glycine- $\mathrm{NaOH}$ buffer (Fig. 1) at $40^{\circ}$. The apparent $K_{m}$ values for NADPH and $(R, S)$-tetrahydrocolumbamine were determined to be 33 and $11 \mu \mathrm{M}$, respectively (Fig. 2). The enzyme was highly substrate specific and would not accept tetrahydroprotoberberine alkaloids (differing from tetrahydrocolumbamine in ring

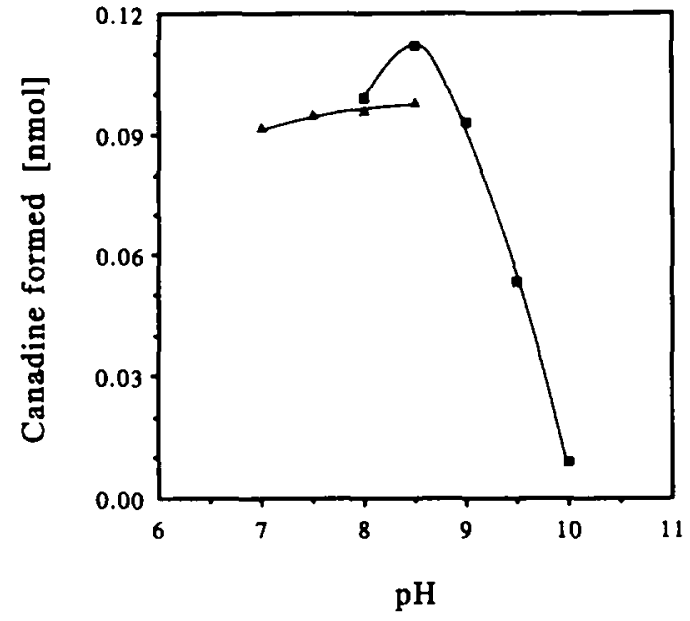

Fig. 1. pH-Dependence of the canadine synthase. The reaction was measured using the standard incubation assay with 0.09 pkat of the enzyme ( $0.65 \mathrm{pkat}_{\mathrm{mg}}^{-1}$ protein) and $50 \mu \mathrm{mol}$ of Tris- $\mathrm{HCl}$ buffer, $\mathrm{pH} 7-8.5,(\Delta-\Delta)$ or glycine- $\mathrm{NaOH}$ buffer,

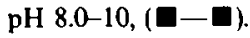
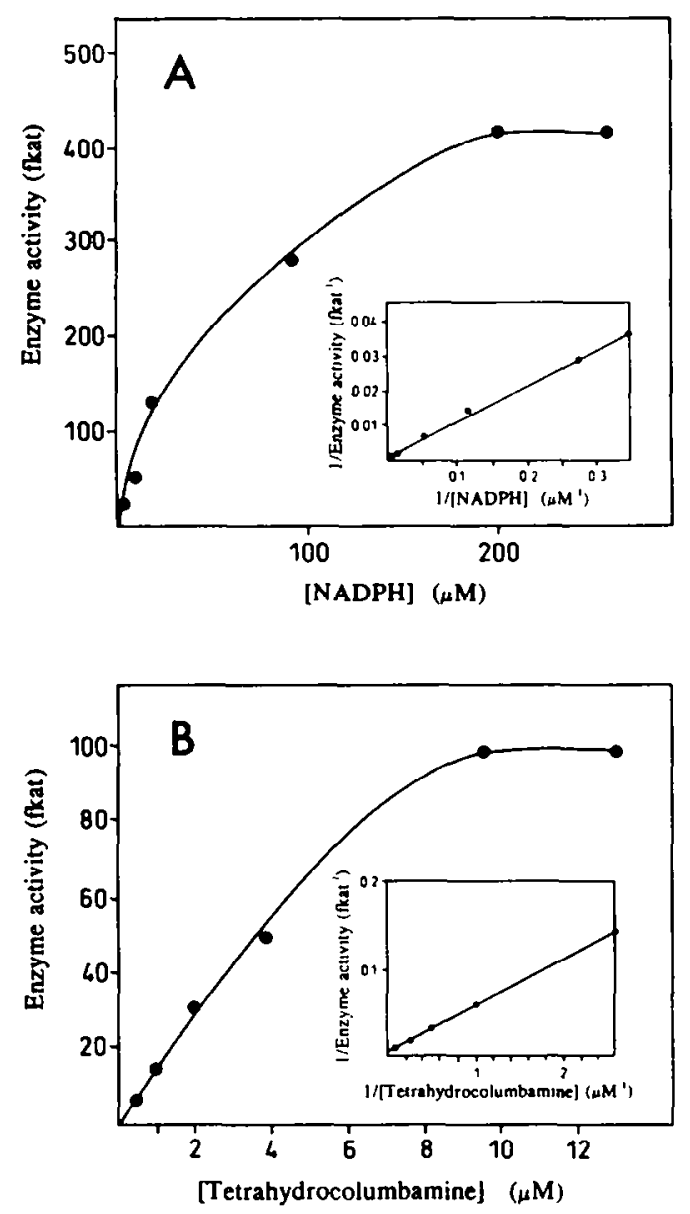

Fig. 2. The effect of NADPH (A) and tetrahydrocolumbamine (B) concentration on the microsomal bound canadine synthase activity. The insert depicts the double reciprocal plot. Standard incubation assays with varying NADPH or tetrahydrocolumbamine concentrations and 0.1 pkat of the enzyme were used. 
Table 4. Substrate specificity of microsomal bound canadinc synthase from $T$. tuherosum cell cultures under standard assay conditions

\begin{tabular}{ll}
\hline Substrate & $\begin{array}{l}\text { Product formed } \\
\text { (pmol) }\end{array}$ \\
\hline (R,S)-Tetrahydrocolumbamine & 160 \\
(S)-Tetrahydrocolumbamine & 155 \\
(R)-Tetrahydrocolumbamine & 0 \\
Columbamine & 0 \\
(R,S)-Tetrahydrojatrorrhizine & 0 \\
(R,S)-Cheilanthifoline & 0 \\
(R,S)-Nandinine & 0 \\
(R.S)-Tetrahydrogrocnlandicine & 0 \\
$(R, S)$-Tetrahydrothalifaurinc & 0 \\
\hline
\end{tabular}

For determination of the substrate specificity $0.5 \mathrm{nmol}$ of the corresponding alkaloid were added to the standard assay.

A or ring $D$ substitution) as substrate (Table 4). In addition, the protoberberine alkaloid, columbamine, was not transformed. This again demonstrates that the pathway from tetrahydrocolumbamine to berberine proceeds through canadine, not through columbamine as previously suggested $[6,10]$ for Berberis. Of a wide variety of $C$-ring reduced protoberberine substrates, only tetrahydrocolumbamine was transformed. Moreover, like other enzymes in the protoberberine pathway [10], the canadine synthase showed strong stereospecificity, accepting only (S)-tetrahydrocolumbamine as substrate but not its (R)-congener (Table 4).

Canadine synthase is a unique microsomal bound cytochrome P-450 enzyme which occurs in berberineproducing cell cultures within the Berberidaceae and Ranunculaceae. The enzyme accepts exclusively (S)tetrahydrocolumbamine as substrate and converts it to (S)-canadine. Although the canadine formed in the microsomal preparations was immediately oxidized to berberine by an (S)-tetrahydroprotoberberine oxidase contamination in this subcellular fraction, the stereochemical configuration of the canadine was without doubt the $S$-epimer due to the stereospecificity of STOX [12]. Had the canadine that was formed been the $R$ epimer, it would have accumulated during the assay.

Canadine synthase catalyses the penultimate step in berberine biosynthesis (Fig. 3). The final stcp in the pathway, the aromatization of ring $C$, is catalysed by $(S)$ tetrahydroprotoberberine oxidase [12] in the Berberidaceae and by a slightly different enzyme in the Ranunculaceae (i.e. Coptis [19] and Thalictrum [Galneder and Zenk, unpublished data]). In both families, the end product alkaloid is berberine. This investigation completes our knowledge of the biosynthesis of berberine starting from two molecules of the primary metabolite, l-tyrosine. A total of 13 enzymes are involved in the formation of this pharmacologically valuable alkaloid.

\section{FXPERIMENTAL}

Plant material. All cell culture were provided by the cell culture laboratory of this department. The cells were grown in 11 flasks containing $250 \mathrm{ml}$ Linsmaier and Skoog medium [20] over a period of 7 days at 23 on a gyratory shaker $(100 \mathrm{rpm})$ at 750 lux. For partial characterization of the enzyme, a protoberberine producing cell line of Thalictrum tuberosum was used. Inoculated with $35 \mathrm{~g}$ fr. wt the 11 conical flasks were harvested after one week by suction filtration yielding $230 \mathrm{~g} \mathrm{fr}$. wt corresponding to $6.7 \mathrm{~g}$ dry wtl 1 medium. The cells were deep frozen with liquid nitrogen and used immediately.

Radiochemicals. $\quad(R, S)-\left[3-\mathrm{O}^{14} \mathrm{CH}_{3}\right]$ Tetrahydrocolumbamine was synthesized from 2,3-dihydroxy-9,10-dimethoxyprotoberberine by incubation with $\left[{ }^{14} \mathrm{CH}_{3}\right]$ $S$-adcnosyl-L-methionine (SAM) and catechol-O-methyltransferase (Sigma). The columbamine formed was reduced with $\mathrm{NaBH}_{4}$ and the product purified by TLC (Polygram Sil G/UV 254 , Machercy and Nagel, toluene-EtOAc-diethylamine, $\left.7: 2: 1 \quad R_{f} 0.5\right)$. The isolated $(R, S)-\left[3-O-{ }^{14} \mathrm{CH}_{3}\right]$ tetrahydrocolumbamine had a specific activity of $56 \mu \mathrm{Ci} \mu \mathrm{mol}{ }^{1}$. Due to the lack of regiospecificity of the porcine catcchol-O-methyltransferase, $(R, S)-\left[2-0-{ }^{14} \mathrm{CH}_{3}\right]$ tetrahydrojatrorrhizine $\left(R_{f} 0.4\right)$ was formed to approximately $10 \%$ as a by product of the enzymic synthesis. $(R, S)-\left[3-\mathrm{O}^{14} \mathrm{CH}_{3}\right]$ Cheilanthifoline, $(R, S)-\left[2-O_{-}{ }^{14} \mathrm{CH}_{3}\right]$ tetrahydrogroenlandicine and $(S)-[10-$ $\left.O-{ }^{14} \mathrm{CH}_{3}\right]$ nandinine were synthesized according to ref. [4]. $\left[{ }^{14} \mathrm{CH}_{3}\right]$ Mcthionine was purchased from Amersham (U.K.) and bioconverted to radiolabelled SAM by the action of SAM-synthetase isolated from Escherichia coli EWH47 according to ref. [21].

Standard enzyme assay. (R,S)-[3-O- $\left.{ }^{14} \mathrm{CH}_{3}\right]$ Tetrahydrocolumbamine $(0.5 \mathrm{nmol}, 40000 \mathrm{cpm}), 10 \mathrm{nmol}$

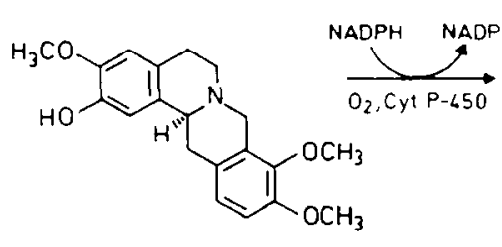

(S)-Tetrahydrocolumbamıne

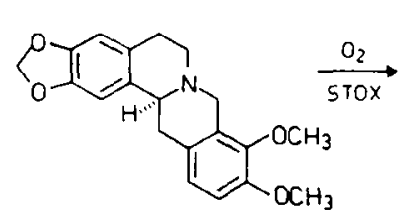

(S)-Canadine

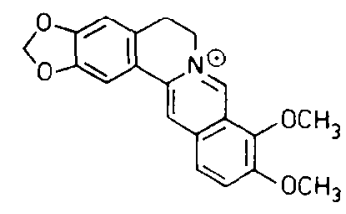

Berberıne

Fig. 3. Reaction scheme of the final two steps in the biosynthesis of the protoberberine alkaloid, berberine. The first step leading from tctrahydrocolumbaminc to canadine is catalysed by the cytochrome P- 450 enzyme. canadinc synthase, the second step leading from canadine to berberine is catalysed by (S)-tetrahydroprotoberberıne oxidase 
$\mathrm{NADPH}, 50 \mu \mathrm{mol}$ glycine- $\mathrm{NaOH}$ buffer, $\mathrm{pH} 8.5$, and $0.1-0.8 \mathrm{mg}$ protein were incubated in a total volume of $300 \mu \mathrm{l}$ for $30 \mathrm{~min}$ at $40^{\circ}$. Assays with boiled enzyme served as control. The incubation was terminated by the addition of $200 \mu 1$ EtOAc, shaken mechanically for $10 \mathrm{~min}$ and the phases sepd by centrifugation at $10000 \mathrm{~g}$ for $3 \mathrm{~min}$ at room temperature. The EtOAc layer was subjected to TLC (Polygram Sil G/UV 2 254, Macherey and Nagel) using cyclohexane-diethylamine $(9: 1)$ as solvent system (columbamine $R_{f} 0.0$, tetrahydrocolumbamine $R_{f}$ 0.1 , berberine $R_{f} 0.5$, canadine $R_{f} 0.8$ ). The chromatograms were scanned and quantitated for radioactivity by a TLC linear analyser (Berthold). Since in these tissue cultures the (S)-tetrahydroprotoberberine oxidase (STOX) [12] is very active and could not be separated from the microsomal frs either by sucrose density centrifugation or by gel filtration on Sephacryl-S-1000 (Pharmacia), the product of the reaction was not canadine, but rather berberine.

Preparation of microsomal fractions. Deep-frozen cells, typcially $100 \mathrm{~g}$ fr. wt, were thawed with the double amount (w/v) $0.1 \mathrm{M}$ Tricine- $\mathrm{NaOH}$ buffer, $\mathrm{pH} 7.5$, containing $1 \mathrm{mM}$ EDTA and $5 \mathrm{mM}$ thioglycolic acid in an ice-cold mortar and stirred with a pestle for about $20 \mathrm{~min}$. After filtration through cheesecloth the crude extract was centrifuged at $10000 \mathrm{~g}$ for $10 \mathrm{~min}$ at $4^{\circ}$. The supernatant was passed through an XAD-2 column $(2.5 \times 15 \mathrm{~cm}$, Serva) that had been equilibrated with the above buffer. The microsomes and vesicles of the alkaloid-free column run-through were harvested by centrifugation at $50000 \mathrm{~g}$ for 30 min at $4^{\circ}$. Addition of $\mathrm{MgCl}_{2}$, as described earlier [22], did not result in higher enzyme activities.

Product identification. For product identification, 20 standard assays were incubated for $30 \mathrm{~min}$, combined and passed over an XAD-2 column (Serva). The alkaloids were eluted with $\mathrm{MeOH}$, concentrated under a stream of $\mathrm{N}_{2}$ and resolved by TLC (Polygram, Macherey and Nagel, solvent system: cyclohexane-diethylamine, 9:1). After determination of the specific activity of berberine $\left(13.3 \times 10^{6} \mathrm{dpm} \mu \mathrm{mol}^{-1}\right)$, this enzymic product was reduced with $\mathrm{NaBH}_{4}$ to $(R, S)$-canadine and chromatographed again in the same solvent system. The specific activity was determined for a second time $\left(11.7 \times 10^{6} \mathrm{dpm}\right.$ $\left.\mu \mathrm{mol}^{-1}\right)$. In addition, the product was diluted with unlabelled canadine $(180 \mathrm{mg}=532 \mu \mathrm{mol})$ and recrystallized $\times 3$ times from $\mathrm{MeOH}$. The specific activity was determined after each crystallization step.

Acknowledgements-Our thanks are due to $\mathrm{Dr} \mathrm{T}$. M. Kutchan for her help in the preparation of this manuscript. This research was supported by SFB 145/369 of the
Deutsche Forschungsgemeinschaft, Bonn, and by Fonds der Chemischen Industrie.

\section{REFERENCES}

1. Scribney, M. and Kirkwood, S. (1953) Nature 171, 931.

2. Barton, D. H. R., Kirby, G. W. and Taylor, J. B. (1962) Proc. Chem. Soc., 340.

3. Barton, D. H. R., Kirby, G. W., Taylor, J. B. and Thomas, G. M. (1963) J. Chem. Soc., 4545.

4. Bauer, W. and Zenk, M. H. (1989) Tetrahedron Letters 30, 5257.

5. Bauer, W. and Zenk, M. H. (1991) Phytochemistry 30, 2953.

6. Rueffer, M. and Zenk, M. H. (1985) Tetrahedron Letters 26, 201.

7. Bauer, W., Stadler, R. and Zenk, M. H. (1992) Botan. Acta 105, 370.

8. Hinz, H. and Zenk, M. H. (1981) Naturwissenschaften 67,620 .

9. Fukui, H., Nakagawa, K., Tsuda, S. and Tabata, M. (1982) in Plant Tissue Culture 1982 (Fujiwara, A., ed.), p. 313. Maruzen Co., Tokyo.

10. Zenk, M. H., Rueffer, M., Kutchan, T. M. and Galneder, E. (1988) in Ciba Foundation Symposium 137, p. 213. John Wiley, Chichester.

11. Sato, E. and Yamada, Y. (1984) Phytochemistry 23, 281.

12. Amann, M., Nagakura, N. and Zenk, M. H. (1988) Eur. J. Biochem. 175, 17.

13. Amann, M., Wanner, G. and Zenk, M. H. (1986) Planta 167, 310.

14. Gerardy, R. and Zenk, M. H. (1993) Phytochemistry 32, 79.

15. Kochs, G. and Grisebach, H. (1987) Z. Naturforsch. 42c, 343.

16. Muto, N., Inouye, K., Inada, A., Nakanishi, T. and Tan, L. (1987) Biochem. Biophys. Res. Commun. 146, 487.

17. Omura, T. and Sato, R. (1964) J. Biol. Chem. 239. 2370.

18. Higashi, K. (1985) GANN Monogr. Cancer Res. 30 , 49.

19. Okada, N., Shinmyo, A., Yamada, Y. (1988) Phytochemistry 27, 979.

20. Linsmaier, E. M. and Skoog, F. (1965) Physiol Plant. 18,100 .

21. Markham, G. D., Hafner, E. W., Tabor, C. W. and Tabor, H. (1980) J. Biol. Chem. 255, 9082.

22. Diesperger, H., Mueller, C. R. and Sandermann, H. (1974) FEBS Letters 43, 155. 